\title{
The effect of algal biomass on the removal of faecal coliform from domestic wastewater
}

\author{
E. D. O. Ansa $\cdot$ H. J. Lubberding $\cdot$ H. J. Gijzen
}

Received: 17 August 2011/Accepted: 18 December 2011/Published online: 4 January 2012

(C) The Author(s) 2012. This article is published with open access at Springerlink.com

\begin{abstract}
The effect of algal density on faecal coliform (FC) decay under conditions of light and darkness were monitored in low and medium strength wastewater and in a 'mixture of treated and raw wastewater' depicting conditions of a variety of dissolved organic compounds. Rates of decay of FC varied in darkness with varying chlorophyll-a concentrations, supporting the hypothesis that algae may produce substances that are toxic to FC. The first empirical evidence that an optimum chlorophyll-a concentration $\left(10 \pm 2 \mathrm{~m} \mathrm{~L}^{-1}\right)$ for maximum $\mathrm{FC}$ destruction in wastewater exist is reported. Rate of decay was higher in medium strength wastewater compared with low strength wastewater at higher algal densities of $\geq 13.9 \mathrm{mg} \mathrm{L}^{-1}$ chlorophyll-a both in light and in darkness, while addition of fresh wastewater to an ongoing wastewater treatment process may lower the rate of FC decay for a wide range of algal densities (0.6-19.6 $\left.\mathrm{mg} \mathrm{L}^{-1}\right)$, under light conditions.
\end{abstract}

Keywords Algae $\cdot$ Decay $\cdot$ Organic matter $\cdot$ Wastewater

E. D. O. Ansa $(\bowtie)$

CSIR Water Research Institute, P O Box AH 38, Achimota, Accra, Ghana

e-mail: edoansa@yahoo.com

H. J. Lubberding

UNESCO-IHE Institute for Water Education, P O Box 3015 DA,

Delft, The Netherlands

e-mail: h.lubberding@unesco-ihe.org

H. J. Gijzen

UNESCO Regional Science Bureau for Asia and the Pacific,

Jl. Galuh II, no.5, Kebayoran Baru, Jakarta 12110, Indonesia

e-mail: h.gijzen@unesco.org

\section{Introduction}

Algal growth in wastewater treatment ponds leads to increases in $\mathrm{pH}$ and dissolved oxygen concentration which may render the aquatic environment hostile to faecal coliforms (FC). Curtis et al. (1992) showed that sunlight damaged FC in waste stabilization ponds, the rate of damage being proportional to the oxygen concentration. Sunlight inactivation of Escherichia coli is known to increase strongly with $\mathrm{pH}$ greater than 8.5 (Davies-Colley et al. 1999). In addition, $\mathrm{pH}$ also acts synergistically with dissolved oxygen in a process known as photo-oxidation to achieve die-off of FC (Maynard et al. 1999). Van der Steen et al. (2000) showed that light attenuation occurs at high chlorophyll-a concentrations and rapid algal growth that occurs in tropical regions may compromise the gains of increased $\mathrm{pH}$ and oxygenation. They hypothesized that optimum chlorophyll-a concentration of algae may exist whereby maximum FC die-off is achieved. This was however not proven by experimentation. Ansa et al. (2011) showed using laboratory-simulated lake conditions that an optimum algal density where maximum FC is inactivated could exist in a eutrophic lake but this hypothesis had not been tested in wastewater treatment systems. One of the objectives of this study is to test whether there indeed exist optimum chlorophyll-a concentration for maximum FC decay in domestic wastewater treatment under batch, laboratory conditions.

The role of organic matter in FC removal in domestic wastewater is still a subject that is not well understood. Dissolved organic matter (DOM) in domestic wastewater, depending on its origin, may act as sensitizers, absorbing long wavelengths of electromagnetic radiation and transmitting it to faecal bacteria cell membranes leading to their subsequent destruction (Curtis et al. 1992; Sinton et al. 
2002). At the same time, some DOM could inhibit short wavelengths in waste stabilization ponds (Curtis et al. 1994; Maynard et al. 1999) and also promote FC survival by providing their carbon and energy needs (Bouteleux et al. 2005). Based on the BOD, Metcalf and Eddy (2003) classified raw domestic wastewater as low strength or weak (110 $\left.\mathrm{mg} \mathrm{L}^{-1}\right)$, medium strength $\left(200 \mathrm{mg} \mathrm{L}^{-1}\right)$ and strong (400 $\mathrm{mg} \mathrm{L}^{-1}$ ). As the concentration of sensitizers affects die-off of FC (Curtis et al. 1992), and would vary in wastewater of different strengths, it is hypothesized that the effect of algal biomass on FC die-off would vary in wastewater of different strengths. This phenomenon is not reported in literature. Algal cells release low molecular weight DOM by secretions and autolysis and the rate of release of these DOM varies with algal density and environmental conditions (Wetzel 2001). As algal organic matter (AOM) enhances the survival of FC (Bouteleux et al. 2005), depending on the variety of individual DOM present, DOM may either support the survival or destruction of FC. This is what occurs in full scale stabilisation ponds. In order to simulate real pond conditions in a batch laboratory experiment, a wide variety of DOM is expected to be present in mixing raw and partially decomposed wastewater. It is therefore suggested that a 'mixture' of first and second feeds of domestic wastewater (consisting of domestic wastewater that had undergone some decomposition or treatment and raw domestic wastewater, respectively) would comprise of DOM of varying quality and quantity and as such should affect the rate of inactivation of FC differently from having either of the two wastewater types. This study aims to understand in addition to the objective mentioned above, the effect of varying concentrations of algal biomass in low/weak and medium strength wastewater on FC removal under batch laboratory conditions and how this effect is affected by a 'mixture' of first and second feeds of raw domestic wastewater depicting a variety of organic matter.

\section{Materials and methods}

Algae culture and preparation

Algae were grown in the laboratory by inoculation of nutrient solution (APHA 2005) with laboratory stock of Chlorella $s p$. obtained from Wilson Group Inc., USA (Wilson Group 2010) under light of wavelength 380-780 nm provided by a powerstar HQI-BT 400 lamp. Culture solution contained $13.5 \mathrm{mg} \mathrm{L}^{-1}$ of nitrogen and $2.2 \mathrm{mg} \mathrm{L}^{-1}$ of phosphorus in the form of nitrate and phosphate, respectively, and kept at $20-25^{\circ} \mathrm{C}$ temperature conditions. Resulting algae were harvested after 14 days, sieved using 250- and 90- $\mu \mathrm{m}$ mesh nets and concentrated by centrifugation at $1,000 \mathrm{rpm}$ for $30 \mathrm{~min}$ into a thick algal paste. Raw domestic wastewater (characteristics shown in Table 1) from the inlet of a wastewater treatment plant at Hoek van Holland, The Netherlands, was stored in a refrigerator for $4 \mathrm{~h}$ before using it for the experiments.

Optimum algal density determination

Algal paste was used to inoculate 20 Erlenmeyer flasks containing $200 \mathrm{~mL}$ of raw wastewater. The averages of the initial and final concentrations of algae in the flasks after 7 days of incubation were as follows: 0, 1.2, 1.7, 6.7 and $17.5 \mathrm{mg} \mathrm{L}^{-1}$ of chlorophyll-a, determined using NEN 6520 (1981). Control flasks had no algae. The various algal incubations or treatments had corresponding initial FC concentration of $8.23 \times 10^{7}, 8.25 \times 10^{7}, 8.27 \times 10^{7}$, $8.32 \times 10^{7}$ and $8.41 \times 10^{7} \mathrm{cfu} 100 \mathrm{~mL}^{-1}$. Six replicates of each treatment were randomly arranged on a shaker (model GFL 3019) and run at $120 \mathrm{rpm}$. The six replicates were kept under alternating light and dark conditions. In the light condition, the replicates were kept $0.8 \mathrm{~m}$ below the HQI-BT 400 lamp for $16 \mathrm{~h}$ per day. In the dark conditions, the replicates were covered with four layers of black polyethylene sheet. After $24 \mathrm{~h}$ of incubation, samples were taken from each flask, and pushed through syringes fitted with needles to detach any attached bacteria (Ansa et al. 2009) and results (not reported here) showed that FC numbers before and after detachment were statistically comparable and were therefore not attaching to algae.

Faecal coliform numbers, dissolved oxygen concentration and $\mathrm{pH}$ were monitored using the spread plate technique (APHA 2005) on chromocult agar medium incubated for $24 \mathrm{~h}$ at $35-37^{\circ} \mathrm{C}$ (Finney et al. 2003), portable WTW330 oxygen meter and WTW340 pH meters, respectively. Decay rates of FC $K_{\mathrm{d}}$ for the different treatments were determined for the period of incubation and these were statistically compared using independent sample $t$ test of SPSS 12.0 statistical package. The decay rates,

Table 1 Physico-chemical characteristics of influent wastewater from January to November 2009

\begin{tabular}{ll}
\hline Parameter $\left(\mathrm{mg} \mathrm{L}^{-1}\right)$ & Value \\
\hline TSS & $242 \pm 53$ \\
BOD & $163 \pm 46$ \\
Nitrate nitrogen & BDL \\
Nitrite nitrogen & BDL \\
Total Kjeldahl nitrogen & $36.7 \pm 10.8$ \\
Total phosphorus & $7.2 \pm 2.1$ \\
\hline
\end{tabular}

Source (HHR 2009)

$B D L$ below detectable limits, $n=28$ 
$K_{\mathrm{d}}$ were calculated from the regression line of the first order decay equation (1) (Marais 1974):

$\ln N_{t}=-K_{\mathrm{d}} t+\ln N_{\mathrm{o}}$

where

$N_{t}=$ FC count per $100 \mathrm{~mL}$ at a time $t$

$N_{\mathrm{o}}=\mathrm{FC}$ count per $100 \mathrm{~mL}$ at the start of the experiment

$t \quad=$ Time (days) of incubation

Faecal coliform decay in low and medium strength wastewater

In order to compare how FC decay rates vary with varying algal biomass in wastewater of different strengths, the procedure outlined above was repeated using low strength wastewater (LSW) $\left(78 \pm 19 \mathrm{mg} \mathrm{L}^{-1} \mathrm{BOD}_{5}\right)$ and medium strength wastewater $\left(162 \pm 46 \mathrm{mg} \mathrm{L}^{-1} \mathrm{BOD}_{5}\right)$ at the same time and conditions. Algal concentrations were deliberately chosen to differ from concentrations of previous experiment so as to be able to observe the effect of these algal concentrations as well. To obtain LSW, raw wastewater, classified as medium strength (MSW) based on the BOD (Metcalf and Eddy 2003), was diluted in the ratio of $1: 1$ by adding an equal volume of demineralised water (Awuah et al. 2004). After inoculation of wastewater with algal paste, the following algal concentrations: 0, 3.2, 13.9, and $20.0 \mathrm{mg} \mathrm{L}^{-1}$ chlorophyll-a were obtained for both LSW and MSW. Control flasks had no algae. Starting FC concentrations of MSW were 7.70, 7.76, 7.86 and $7.96 \times 10^{7} \mathrm{cfu} 100 \mathrm{~mL}^{-1}$ for the respective algal treatments. Monitoring of dissolved oxygen concentration, $\mathrm{pH}$, FC and determination of $K_{\mathrm{d}}$ and its statistical analysis were done as mentioned in the previous experiment.

Effect of second feed of raw wastewater on faecal coliform decay

The effect of a mixture of a 10-day treated wastewater and a second feed of raw wastewater on FC decay was investigated to understand how this unique composition of wastewater affects FC decay. The experimental set-up above was repeated except for the range of algal concentrations chosen $\left(0,0.6,1.7\right.$, and $19.5 \mathrm{mg} \mathrm{L}^{-1}$ chlorophyll-a), starting FC concentrations (3.70, 3.71, 3.72 and $3.82 \times$ $10^{7} \mathrm{cfu} 100 \mathrm{~mL}^{-1}$, respectively) and period of incubation (10 days). The above algal concentrations were chosen based on the results of previous experiments which show that big differences are likely to be revealed by that range of algal density. The 10-day period of incubation was chosen in order to observe any possible changes that might occur after 7 days of incubation. After 10-day incubation (end of phase one), additional $200 \mathrm{~mL}$ of raw wastewater was added to each flask (as beginning of phase two). Monitoring of dissolved oxygen concentration, $\mathrm{pH}, \mathrm{FC}$ and determination of $K_{\mathrm{d}}$ for phases one and two and its statistical analysis were done as mentioned in the previous experiments. BOD concentration of incubations was not monitored as withdrawal of samples for BOD analysis, volume-wise, would interfere with the assessment of FC decay and therefore dissolved oxygen profile was used to explain possible changes in BOD.

\section{Results}

Optimum algal density determination

In light algal incubations, $\mathrm{pH}$ and dissolved oxygen concentrations were higher than those in darkness and exceeded 10.0 and $8.5 \mathrm{mg} \mathrm{L}^{-1}$, respectively (Fig. 1). The rate of FC decay varied with varying chlorophyll-a concentrations. An optimum curve $\left(R^{2}=0.80, n=24\right)$, with maximum decay rates occurring at $10.0 \pm 2 \mathrm{mg} \mathrm{L}^{-1}$ chlorophyll-a was observed. Lower decay rates were associated with high chlorophyll-a concentrations (Fig. 1). Algae still had an effect on FC decay in darkness. A positive linear correlation was observed between chlorophyll-a concentration and decay rates in darkness $\left(R^{2}=0.77, n=30\right)$, with lower decay rates associated with lower chlorophyll-a concentrations. For all the chlorophyll-a concentrations used, significantly higher die-off rates of FC were observed in light compared to darkness ( $p<0.001$, Fig. 1). Variation in the $t$ value when light and darkness decay rates were compared using the students $t$ test suggests a complex interaction of light with other factors such as $\mathrm{pH}$ and DO to achieve die-off.

Decay of faecal coliform in low and medium strength wastewater

Mixing of wastewater with demineralised water to prepare low strength wastewater aerated the light and darkness incubations even before the start of the experiment and stirring of incubations also introduced some atmospheric oxygen into the incubations. Comparable values of $\mathrm{pH}$ and DO over time were observed in LSW and MSW in light and darkness, respectively (Fig. 2). Generally, decay rates in light were significantly higher than that in darkness for both LSW and MSW (Fig. 3). At higher algal densities $\geq 13.9 \mathrm{mg} \mathrm{L}^{-1}$ in light, significantly higher decay rates were observed in MSW compared to LSW $(p<0.05)$. Optimum algal densities (algal densities for maximum decay of FC) in light were different for LSW and MSW occurring at 3.2 and $13.9 \mathrm{mg} \mathrm{L}^{-1}$ chlorophyll-a concentrations, respectively. 
Fig. 1 Conditions of $\mathrm{pH}(\mathbf{a})$, dissolved oxygen concentration (b) and rates of faecal coliform decay, $K_{\mathrm{d}}(\mathbf{c})$ at different chlorophyll-a concentrations during period of incubation in light and darkness, taken at 10.00-11.00 a.m. Standard deviation in (a) and (b) represents variations during period of incubation
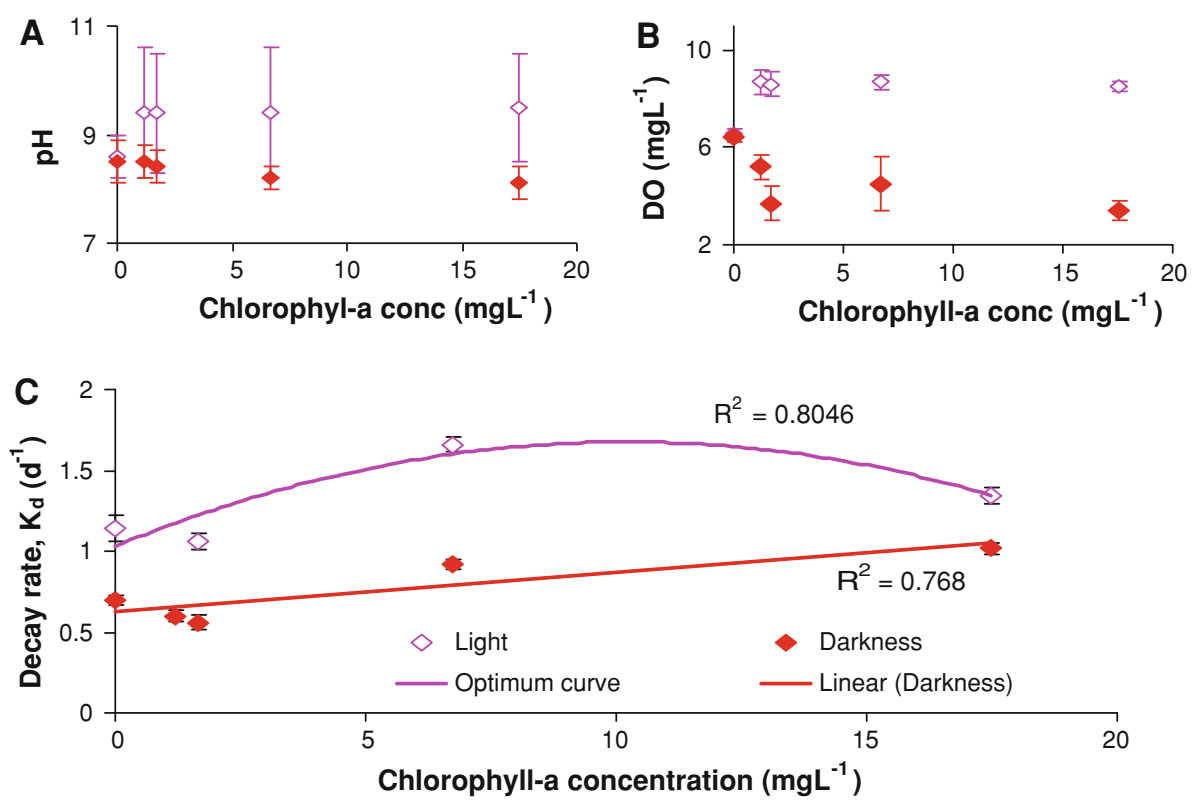

Decay rates occurring at the optimum algal densities for LSW and MSW were, however, comparable statistically. At chlorophyll-a concentration of $20.0 \mathrm{mg} \mathrm{L}^{-1}$ in darkness, decay rates in MSW were higher than in LSW. Below this algal density (20.0 $\mathrm{mg} \mathrm{L}^{-1}$ ), comparable decay rates were observed for LSW and MSW in darkness (Fig. 3).

Effect of second feed of raw wastewater on faecal coliform decay

Introduction of second feed of wastewater led to lower values of $\mathrm{pH}$ and $\mathrm{DO}$ in light. In darkness, $\mathrm{pH}$ and DO levels before and after second feed of wastewater were similar (Fig. 4). Decay rates of FC in phases 1 and 2 were compared. Lower decay rates were observed in phase 2 incubations exposed to light (Fig. 5). The survival or decay of FC in experiments kept in darkness was not affected by the second feed of wastewater.

\section{Discussion}

Optimum algal density

Considering the concentrations of algae used in this experiment, rates of decay of FC were higher in light than in darkness (Fig. 1). The present work including some recent work (Shilton et al. 2008), shows that light plays an important role in the inactivation of FC contrary to some earlier work that disputed this (Maynard et al. 1999). Higher decay rates were observed in the presence of algae and the differences in decay rates can be attributed to the differences in chlorophyll-a concentration. Decay rates increased with increased chlorophyll-a concentration till a certain optimum $\left(10 \pm 2 \mathrm{mg} \mathrm{L}^{-1}\right)$ after which decay rates decreased with increased chlorophyll-a concentration (Fig. 1). Algal presence leads to $\mathrm{pH}$ elevation and increased oxygen concentration, both of which are bactericidal to FC (Davies-Colley et al. 1999; Awuah et al. 2001). Decay rates of FC have been observed to increase with increased dissolved oxygen concentration (Curtis et al. 1992). Curtis et al. (1992) explained that in the presence of light, toxic forms of oxygen molecules are produced (notably peroxides and singlet oxygen), which increase in concentration with increased DO concentration. These toxic forms of oxygen are injurious to bacteria, particularly its cytoplasmic membrane. They also observed that light-mediated damage of FC is highly sensitive to elevated $\mathrm{pH}$ values which enables light of wavelengths $>425 \mathrm{~nm}$ (in the presence of a sensitizer) to damage the bacteria. This may explain the increases in decay rates with increased $\mathrm{pH}$ and DO concentrations. At high chlorophyll-a concentration, algal presence could lead to light attenuation, with highly turbid systems having greater attenuation thus reducing the effect of shorter wavelengths of electromagnetic radiation (Van der Steen et al. 2000), leading to lower decay rates of FC.

Effect of algae in darkness

Increased FC decay rates in darkness with increased chlorophyll-a concentration suggest an effect of algae even in darkness. As pH and dissolved oxygen concentrations in algal incubations were similar or comparable, a factor such as an algal toxin or inhibitor that is released during lyses of algal cells (Wetzel 2001; Maynard et al. 1999), and whose 
Fig. 2 Conditions of $\mathrm{pH}$ and dissolved oxygen concentrations in low (LSW) and medium strength wastewater (MSW) inoculated with algae and monitored at 10.00-11.00 a.m.
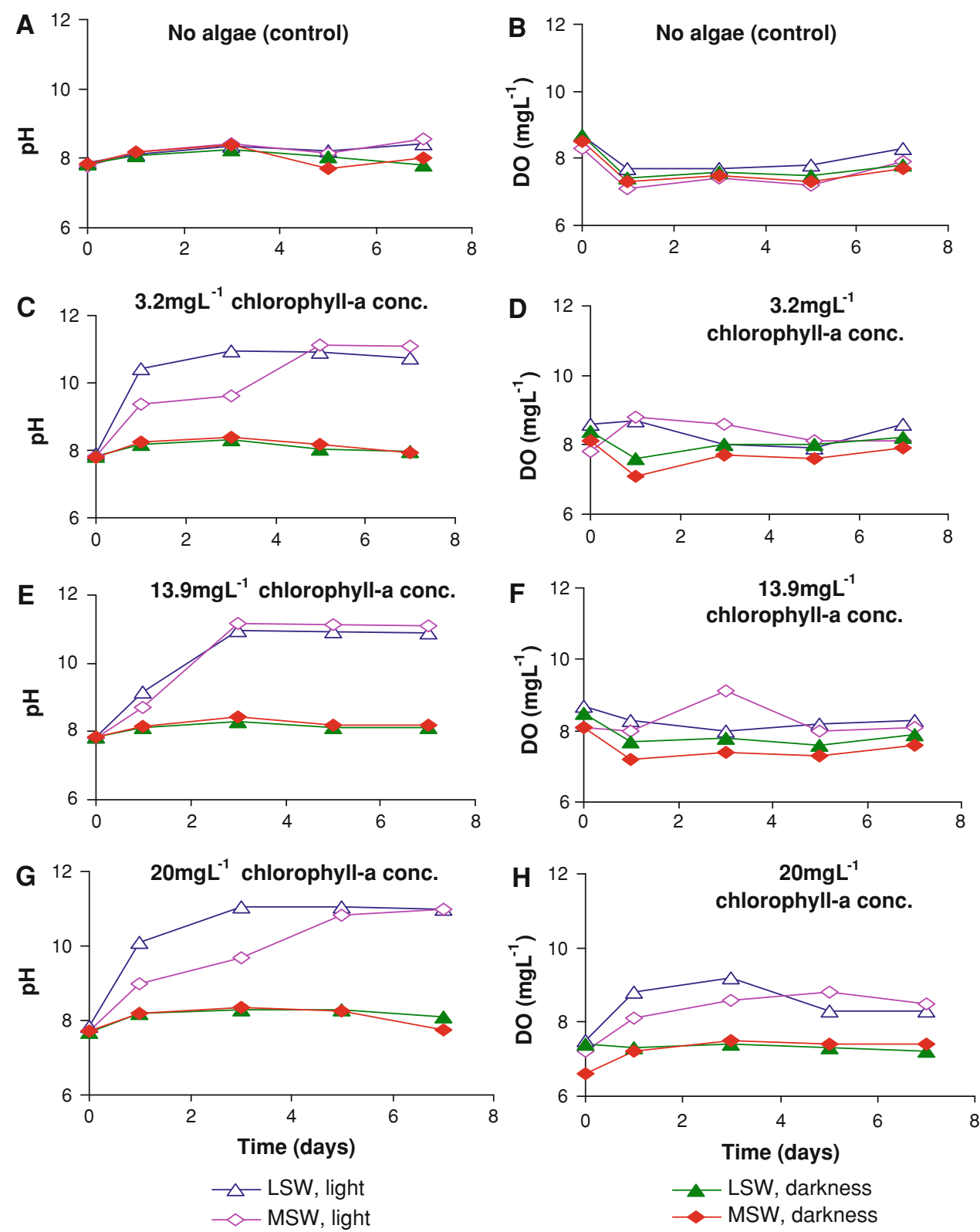

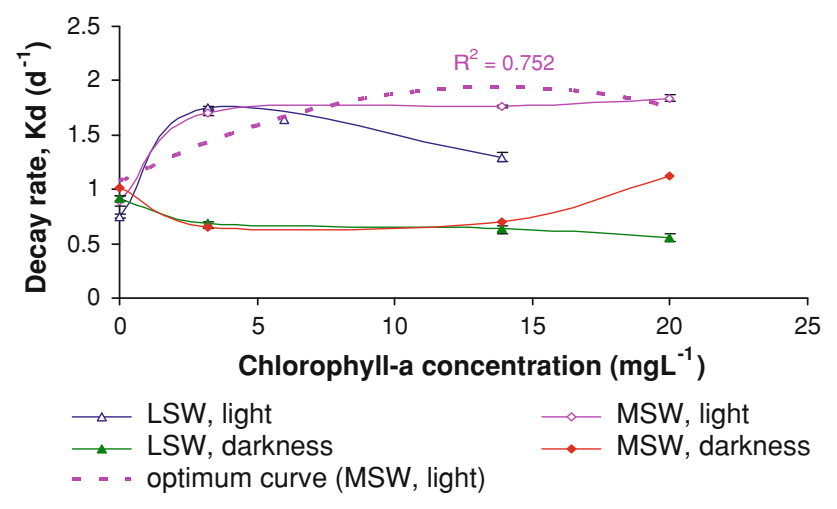

Fig. 3 Decay rates of faecal coliforms, $K_{\mathrm{d}}$ in low (LSW) and medium strength wastewater (MSW) inoculated with algae and monitored at 10.00-11.00 a.m. concentration increases with increased chlorophyll-a concentration may be inactivating FC. The role of algal toxin in the inactivation of FC is still a subject of great debate (Maynard et al. 1999) and this observation gives credence to the existence of such toxins that inactivates FC.

Decay of faecal coliform in low and medium strength wastewater

At chlorophyll-a concentration $\leq 3.2 \mathrm{mg} \mathrm{L}^{-1}$, decay rates in LSW and MSW were comparable (Fig. 3). At higher chlorophyll-a concentrations $\left(\geq 13.9 \mathrm{mg} \mathrm{L}^{-1}\right)$, decay rates of FC were higher in MSW than in the LSW. At chlorophyll-a concentration of $\leq 3.2 \mathrm{mg} \mathrm{L}^{-1}$, both LSW and 
Fig. 4 Conditions of $\mathrm{pH}$ and dissolved oxygen concentration before and after addition of second feed of raw wastewater monitored at 10.00-11.00 a.m.
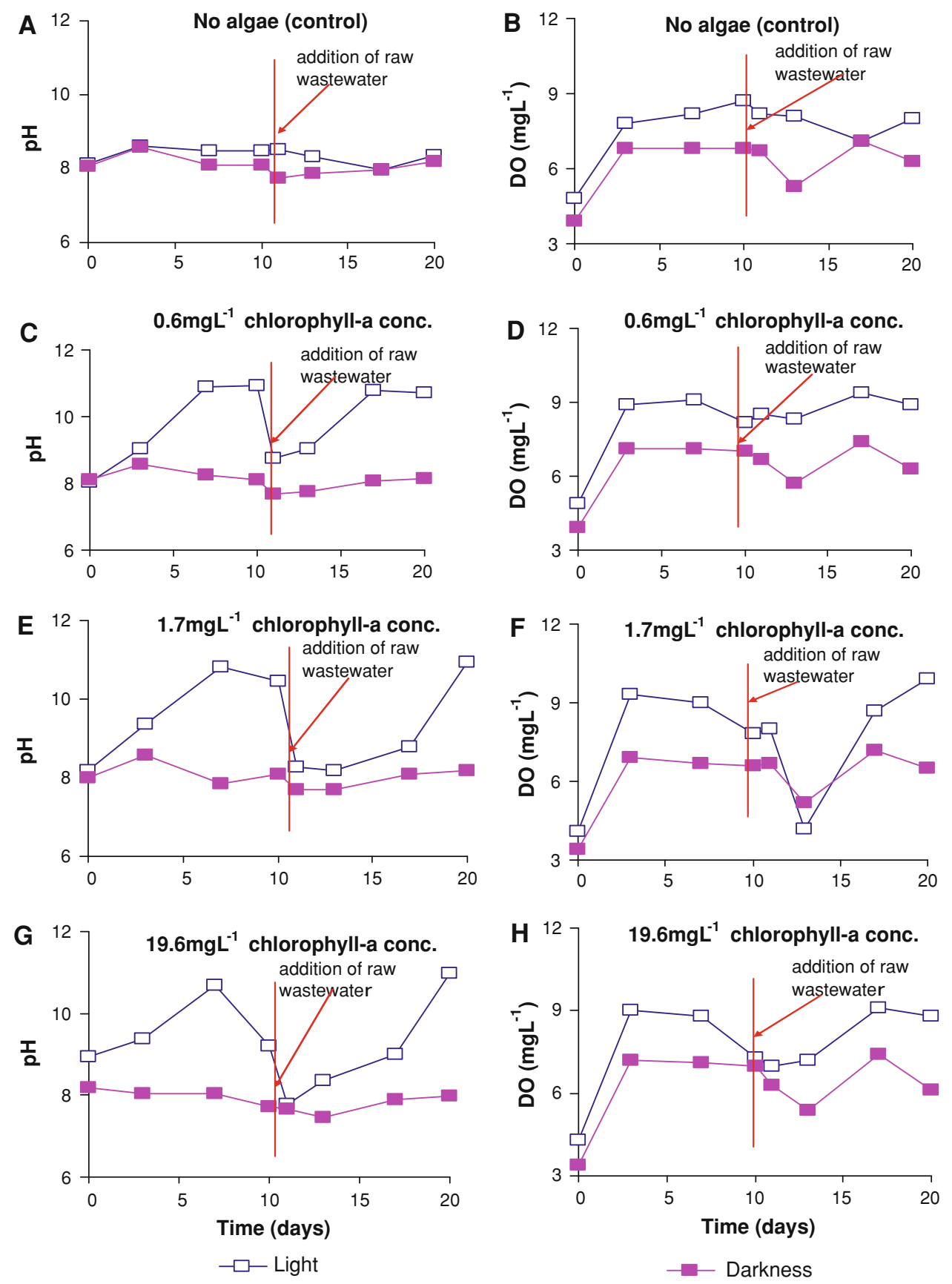

MSW had pH increasing up to a maximum of 10.7 and 11.1, respectively (Fig. 2). These were higher than the critical pH of 9-9.5 that is bactericidal to FC (Maynard et al. 1999). The oxygen concentration ranges of 7.9-8.6 and $7.8-8.8 \mathrm{mg} \mathrm{L}^{-1}$ for LSW and MSW, respectively, were also comparable. The higher decay rates of FC in MSW can therefore be attributed to the higher organic matter present in the MSW. Some wastewater-derived DOM acts as sensitizers absorbing light energy and passing on this energy to oxygen radicals, resulting in the damage of FC (Maynard et al. 1999) and some sensitizers can themselves injure the cytoplasmic membrane of FC directly (Sinton et al. 2002). Some DOM such as AOM may however promote FC survival by supplying its carbon and energy needs (Bouteleux et al. 2005) and this may explain why the optimum algal densities (algal densities for maximum decay of FC) in light were different for LSW and MSW occurring at 3.2 and $13.9 \mathrm{mg} \mathrm{L}^{-1}$, respectively. Algal cells release DOM by secretions and autolysis and the rate of release of these DOM increases with increased chlorophyll-a concentration (Wetzel 2001). Thus, the optimum algal densities may occur at concentrations of 
Fig. 5 Decay rates $K_{\mathrm{d}}$ of faecal coliforms before (phase 1) and after (phase 2) second feed of raw wastewater monitored at $10.00-11.00$ a.m. Bar values represent duplicated treatments each having 3 sub-replicates

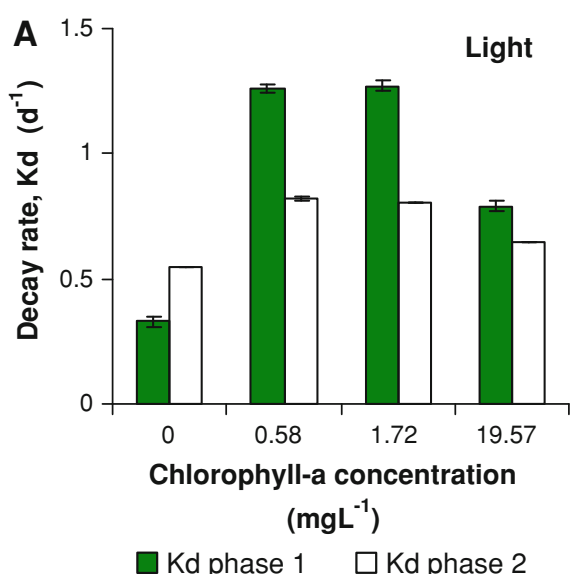

Kd phase $1 \quad \square$ Kd phase 2

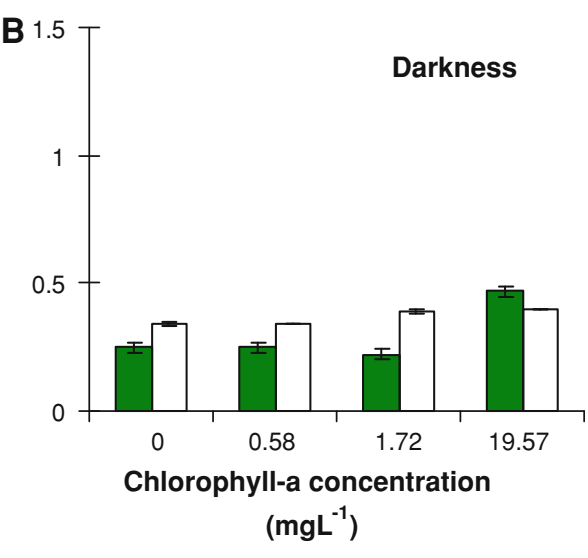

Kd phase $1 \quad \square$ Kd phase 2 algae which may have a net higher concentration of sensitizers as wastewater-derived organic matter as opposed to concentration of growth-promoting organic matter.

Effect of second feed of raw wastewater on faecal coliform decay

The effect of a mixture of dissolved organic compounds (created by mixing a 10-day treated wastewater with raw wastewater) on FC rate of decay was investigated. Increased $\mathrm{pH}$ and oxygenation led to higher rates of $\mathrm{FC}$ decay during phase one light incubations containing algae (Fig. 4) as was also reported earlier in this paper and also by Awuah (2006). The buffering capacity of the raw wastewater lowered the $\mathrm{pH}$ during phase two and increased organic matter content depleted quickly the dissolved oxygen concentration leading to lower $\mathrm{pH}$ and dissolved oxygen concentration and consequently lower decay rates of FC (Fig. 4). Addition of raw wastewater also introduced additional nutrients and organic substrates and therefore extra carbon and energy sources which may enhance the survival of FC (Van der Steen et al. 2000). Expectedly, decay rates in darkness before and after second feed of wastewater did not vary much as sufficient carbon sources may be present in the wastewater for the use of FC.

\section{Conclusions}

- In light, FC rate of decay increased with increased chlorophyll-a concentration till a certain optimum chlorophyll-a concentration $\left(10 \pm 2 \mathrm{mg} \mathrm{L}^{-1}\right)$, after which FC decay rates decreased. The optimum chlorophyll-a concentration is affected by wastewater strength and the quality of dissolved organic compounds present in the raw wastewater. Increase in the quality of dissolved organic compounds through a second feed of raw wastewater led to lower rates of FC inactivation.

- At algal densities $\geq 13.9 \mathrm{mg} \mathrm{L}^{-1}$ in light, rate of decay of FC is higher in MSW than in LSW. The highest rate of decay in LSW occurred at $3.2 \mathrm{mg} \mathrm{L}^{-1}$ in light, while that of the MSW occurred at $13.9 \mathrm{mg} \mathrm{L}^{-1}$ chlorophyll-a concentration, respectively. These have implications for pond designs as ponds with optimal algal densities would tend to be more efficient in FC removal.

- In darkness, algae produced a substance which inactivated FC. Further investigations are needed to ascertain the kind of substance produced.

Acknowledgment The authors are grateful to the Netherlands Government and the Government of Ghana for funding this research through the Netherlands Fellowship Programme (NFP) and the Ghana Educational Trust Fund (GETFUND), respectively. Research facilities provided by the Environmental Engineering Laboratory of UNESCO-IHE Institute for Water Education, Delft, The Netherlands are gratefully acknowledged.

Open Access This article is distributed under the terms of the Creative Commons Attribution License which permits any use, distribution and reproduction in any medium, provided the original author(s) and source are credited.

\section{References}

Ansa EDO, Lubberding HJ, Gijzen HJ (2009) Bacterial attachment and detachment in wastewater treatment systems. In: Proceedings of 1st IWA YWP Benelux conference, IWA-1887, Eindhoven, 30th September-2nd October,

Ansa EDO, Lubberding HJ, Ampofo JA, Gijzen HJ (2011) The role of algae in the removal of Escherichia coli in a tropical eutrophic lake. Ecol Eng 37(2):317-324

APHA (2005) Standard methods for the examination of water and wastewater. In: Greenberg AE, Clesceria LS, Eaton AD (eds), 21st edn. American Public Health Association (APHA), American Water Works Association (AWWA), Washington

Awuah E (2006) Pathogen removal mechanisms in macrophyte and algal waste stabilization ponds. Taylor and Francis/Balkema, Leiden, The Netherlands 
Awuah E, Anohene F, Asante K, Lubberding HJ, Gijzen HJ (2001) Environmental conditions and pathogen removal in macrophyte and algal-based domestic wastewater treatment systems. Water Sci Technol 44:11-18

Awuah E, Oppong-Peprah M, Lubberding HJ, Gijzen HJ (2004) Comparative performance studies of water lettuce, duckweed and algal-based stabilization ponds using low strength wastewater. J Toxicol Env Health, Part A 67:1-13

Bouteleux C, Saby S, Tozza D, Cavard J, Lahoussine V, Hartemann P, Mathieu L (2005) Escherichia coli behaviour in the presence of organic matter released by algae exposed to water treatment chemicals. Appl Environ Microbiol 71:734-740

Curtis TP, Mara DD, Silva SA (1992) Influence of pH, oxygen and humic substances on ability of sunlight to damage FC in waste stabilization pond water. Appl Environ Microbiol 58:1335-1343

Curtis TP, Mara DD, Dixo NGH, Silva SA (1994) Light penetration in waste stabilization ponds. Water Res 28:1031-1038

Davies-Colley RJ, Donnison AM, Speed DJ, Ross CM, Nagels JW (1999) Inactivation of faecal indicator microorganisms in waste stabilisation ponds: interactions of environmental factors with sunlight. Water Res 33(5):1220-1230

Finney M, Smullen J, Foster HA, Brokx S, Storey DM (2003) Evaluation of chromocult agar for the detection and enumeration of enterobacteriaceae from faecal samples from healthy subjects. J Microbiol Methods 54:353-354

HHR (2009) Municipal wastewater characteristics from Hoek van Holland treatment plant. Water Management Authority for Delfland (Hoogheemraadschap Van Delfland), The Netherlands
Marais GR (1974) Faecal bacteria kinetics in stabilization ponds. J Environ Eng (ASCE) 100:119-139

Maynard HE, Ouki SK, Williams SC (1999) Tertiary lagoons: a review of removal mechanisms and performance. Water Res 33:1-13

Metcalf and Eddy (2003) Wastewater engineering: treatment and reuse. 4th edn, McGraw Hill Publication, New York

NEN 6520 (1981) Spectrophotometric analysis after pigment extraction with hot ethanol (Water. Spectrofotometrische bepaling van het gehalte aan chlorofyl-a). Nederlands Normalisatie-instituut (NEN), Delft

Shilton AN, Mara DD, Craggs R, Powell N (2008) Solar-powered aeration and disinfection, anaerobic co-digestion, biological $\mathrm{CO}_{2}$ scrubbing and biofuel production: the energy and carbon management opportunities of waste stabilisation ponds. Water Sci Technol 58(1):253-258

Sinton LW, Hall CH, Lynch PA, Davies-Colley RJ (2002) Sunlight inactivation of faecal indicator bacteria and bacteriophages from waste stabilization pond effluent in fresh and saline waters. Appl Environ Microbiol 68:1122-1131

Van der Steen P, Brenner A, Shabtai Y, Oron G (2000) The effect of environmental conditions on FC decay in post-treatment of UASB reactor effluent. Water Sci Technol 42:111-118

Wetzel RG (2001) Limnology. Academic Press, London

Wilson Group (2010) http://www.wilson-groups.com/products. Accessed August 272010 